\title{
UPAYA PENGELOLAAN MANAJEMEN LINGKUNGAN HIDUP KEGIATAN PEMBANGUNAN RUKO DAN GUDANG REAL ESTATE KABUPATEN BANGKALAN PADA MASA KONSTRUKSI
}

\author{
Diah Ayu Restuti Wulandari ${ }^{1}$ \\ ${ }^{\text {I} D i a h ~ A y u ~ R e s t u t i ~ W u l a n d a r i, ~ U n i v e r s i t a s ~ N a r o t a m a, ~ d i a h . w u l a n d a r i @ n a r o t a m a . a c . i d ~}$
}

\begin{abstract}
ABSTRAK
Kabupaten Bangkalan Madura merupakan salah satu penopang kota metropolitan Surabaya. Akses keluar masuknya yang mudah melalui jembatan Surabaya mendorong redistrifungsi wilayah tersebut. Yang awalnya banyak lahan kosong tak terpakai akhirnya banyak dilirik investor untuk menanam modal usaha disana sehingga pembangunan semakin pesat. Salah satunya dengan pembangunan ruko dan gudang real estate, dimana akibat dari pembangunan tersebut selain memberikan dampak positif seperti menciptakan lapangan pekerjaan baru, mensejahterakan penduduk local namun juga memberikan dampak negative berupa meningkatnya tekanan terhadap lingkungan. Salah satu upaya yang dilakukan untuk mengurangi dampak negative yang timbul dari suatu kegiatan pembangunan maka dilakukan kajian upaya pengelolaan manajemen lingkungan hidup yang didalamnya memuat rencana pengelolaan dan pemantauan lingkungan hidup. Tujuan dari penelitian ini untuk mendapatkan hasil pengelolaan lingkungan hidup baik fisik kimia, social ekonomi beserta cara minimalisasi dampak yang terjadi terutama dengan batasan pada saat masa konstruksi pembangunan ruko dan pergudangan Real Estate kabupaten bangkalan. Pengumpulan data dilakukan dengan observasi pengamatan langsung dilapangan menggunakan wawancara dan kuesioner. Dampak yang ditimbulkan pada masa konstruksi ini berupa Komponen fisik - kimia seperti penurunan kualitas udara, adanya peningkatan kerusakan jalan, kebisingan, peningkatan air limbah domestik dan limbah padat dan komponen sosial ekonomi dimana lebih kepada hubungan dengan masyarakat seperti kekawatiran perekrutan pekerja dari luar bangkalan bukan dari pekerja lokal, peningkatan kepadatan lalu lintas akibat bangkitan yang terjadi dan untuk kecelakaan pekerja. Pencegahan yang dilakukan pada masa konstruksi ini dengan melakukan cara cara untuk meminimalisir dampak melalui pendekatan sosial ekonomi untuk hubungan masyarakat dan teknologi untuk meminimalisir dampak fisik kimia lingkungan.
\end{abstract}

Kata kunci: Upaya Pengelolaan Manajemen lingkungan, pendekatan fisik kimia, pendekatan sosial ekonomi

\section{PENDAHULUAN}

Semua kegiatan pembangunan pada dasarnya menimbulkan dampak terhadap lingkungan baik dampak yang menguntungkan maupun dampak yang merugikan. Lingkungan hidup berdasarkan UU nomor 32 tahun 2009 adalah kesatuan ruang dengan semua benda, daya, keadaan dan mahluk hidup termasuk manusia dan perilakunya yang mempengaruhi alam itu sendiri, kelangsungan perikehidupan dan kesejahteraan manusia serta mahluk hidup lainnya. Oleh karena itu, perlu dikaji tentang perkiraan dampak yang ditimbulkan dari segala aspek mulai dari fisik - kimia maupun social ekonomi serta evaluasi terhadap dampak pentingnya.

Kabupaten Bangkalan Madura merupakan salah satu penopang kota metropolitan Surabaya. Akses keluar masuknya yang mudah melalui jembatan Surabaya mendorong 


\section{NAROTAMA JURNAL TEKNIK SIPIL \\ e-ISSN: 2460-3430 \\ VOLUME 4 NOMOR 2 NOPEMBER 2020}

redistrifungsi wilayah tersebut. Yang awalnya banyak lahan kosong tak terpakai akhirnya banyak dilirik investor untuk menanam modal usaha disana sehingga pembangunan semakin pesat. Salah satunya dengan pembangunan ruko dan gudang real estate, dimana akibat dari pembangunan tersebut selain memberikan dampak positif seperti menciptakan lapangan pekerjaan baru, mensejahterakan penduduk local namun juga memberikan dampak negative berupa meningkatnya tekanan terhadap lingkungan.

Rencana usaha atau kegiatan Ruko Dan Gudang Real Estate yang terletak dijalan Suramadu Desa Petapan Kecamatan Labang Desa Bancang Dan Desa Masaran Kecamatan Tragah Kabupaten Bangkalan, secara geografis berada diantara $7^{\circ} 6^{\prime} 11.18^{\prime \prime}$ LS dan 112 47'54.32" BT ini terbangun diatas lahan seluas 40.708 meter persegi. Berdasarkan Peraturan Daerah Kabupaten Bangkalan No. 10 Tahun 2009 tentang Rencana Tata Ruang Wilayah (RTRW) Tahun 2009-2029, Kegiatan Ruko dan Gudang Real Estate dijalan tersebut memiliki kesesuaian dengan aspek tata ruangnya bahwa lokasi rencana masuk pada wilayah SWP II (dua) yang memiliki fungsi kegiatan diantaranya perikanan, industry dan pergudangan serta transportasi.

Berdasarkan Rencana Pola Ruang pada Rencana Tata Ruang Wilayah (RTRW) Kab. Bangkalan tersebut bahwa lokasi sesuai arahan tata ruang berada di kawasan perdangan dan jasa. Swp ini berperan sebagai pusat pertumbuhan skala pelayanan kabupaten Bangkalan terutama disektor industry dan perdagangan serta transportasi. Hal ini juga sejalan dengan yang tercantum dalam surat informasi Tata Ruang Nomor: 050/618/433.201/2019 Tanggal 6 Mei 2019 yang diterbitkan oleh Badan Perencanaan Pembangunan Daerah Kabupaten Bangkalan.

Pelaksanaan kegiatan ruko dan pergudangan real estate tersebut terdiri dari 32 unit ruko seluas 6075 meter persegi dan 29 unit gudang yang terdiri atas 20 unit untuk gudang type 300 meter persegi dan 9 unit untuk tipe gudang seluas 270 meter persegi. Dimana untuk kegiatannya sendiri ruko dan gudang tersebut akan dijual ke masyarakat sekitar baik di wilayah Madura maupun investor dari Surabaya dan kota industry lainnya.

Pembangunan berkelanjutan menentukan persyaratan kinerja lingkungan yang berdampak baik bagi suatu tatanan ekosistem (slamet, 2007). Untuk itu model manajemen lingkungan yang baik harus melalui kajian dampak yang akan terjadi sebagai akibat adanya suatu usaha dan atau kegiatan. Dampak tersebut merupakan hubungan sebab akibat atau hubungan kausal antara rencana kegiatan dan rona lingkungan hidup dengan dampak yang bersifat negatif dan bersifat positif dan dampak adalah suatu perubahan yang terjadi sebagai akibat suatu aktivitas. Hubungan sebab akibat tersebut dapat bersifat antagonik maupun bersifat sinergistik pada setiap tahapan kegiatan dan pada setiap rincian kegiatan (purbonegoro, 2017). Dampak yang timbul di perlukan pengelolaan dan pemantauan supaya dampak yang timbul tidak mengganggu kegiatan masyarakat sekitar. Adapun tujuan dari penelitian untuk mendapatkan hasil pengelolaan lingkungan hidup baik fisik kimia, social ekonomi beserta cara minimalisasi dampak yang terjadi terutama dengan batasan pada saat masa konstruksi pembangunan ruko dan pergudangan Real Estate kabupaten bangkalan.

\section{METODE}

Penelitian dilakukan di Kecamatan Labang Desa Bancang dan desa Masaran Kecamatan Tragah, lebih tepatnya di kawasan pembangunan ruko dan gudang real estate kabupaten bangkalan sebagaimana pada gambar 1 berikut. 


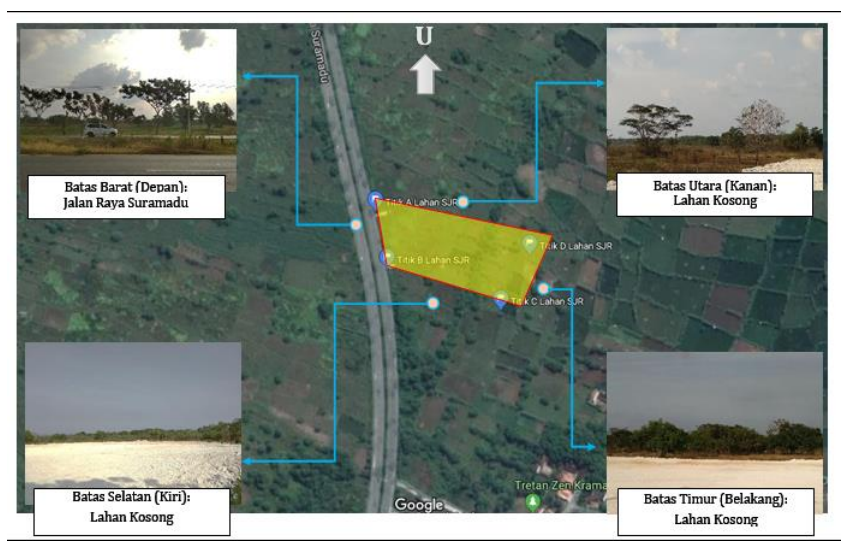

Gambar 1 Lokasi

Sedangkan metode yang digunakan dalam penelitian ini adalah metode observasi dengan memperhatikan ruang lingkup pada proyek tersebut atau yang dinamakan skoping untuk mengetahui dampak dari pembangunan ruko dan gudang real estate bangkalan pada masa konstruksi. Metode observasi disni yakni metode dengan melakukan pengamatan langsung dilapangan atau survey dan dengan memperhatikan ruang lingkup (skoping) maksudnya adalah suatu metode pengelompokan data berdasarkan dampak lingkungan yang terjadi dari berbagai aspek. Beanlands dan duinker (1983) dalam tulisan prasetyo, dkk (2018) ini memberikan pengertian untuk dua macam skoping yakni skoping social dan skoping ekologis. Pengumpulan data dilakukan dengan cara menggunakan pengamatan langsung di lapangan dan wawancara menggunakan kuisioner. Analisa dampak lingkungan yang diperoleh dengan melihat data tambahan pada feasibility study pembangunan ruko dan pergudangan real estate kabupaten bangkalan ini sendiri. Berikut flowchart penelitian yang disajikan pada gambar 2 


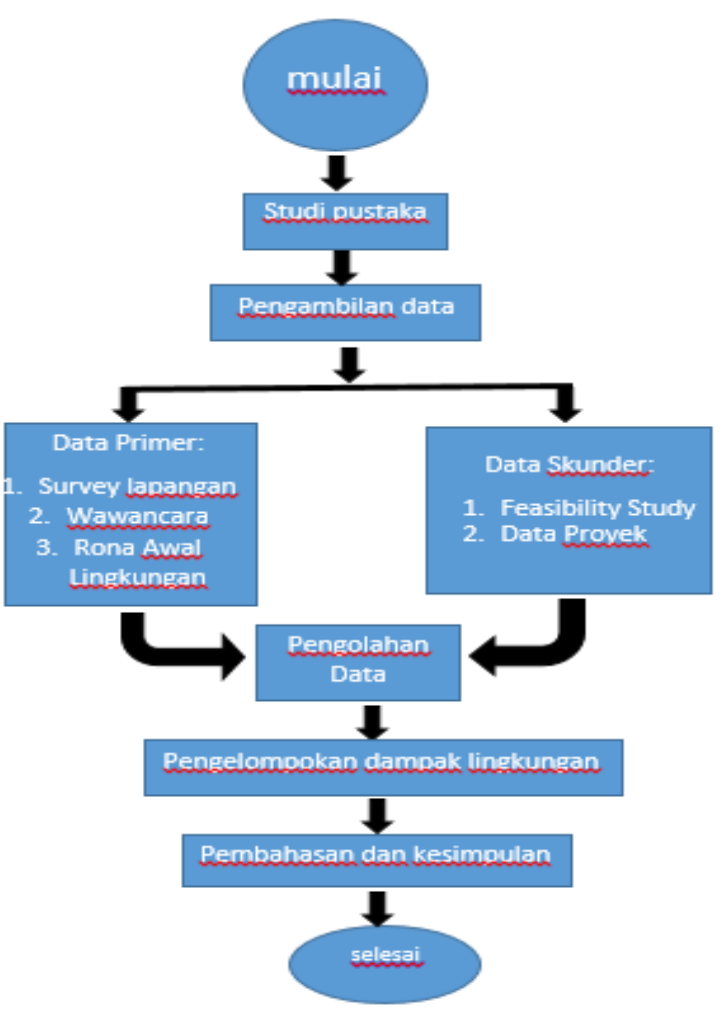

Gambar 2. Flow chart penelitian

\section{HASIL DAN PEMBAHASAN}

Kegiatan konstruksi dari Kegiatan operasional Ruko dan Gudang (Real Estate) Kabupaten Bangkalan ini akan memberikan dampak positif maupun negatif, sehingga dalam pelaksanaannya perlu dilakukan pula upaya pengelolaan lingkungan sehingga dapat diidentifikasi dampak-dampak yang kemungkinan akan terjadi beserta cara pengelolaan maupun pemantauannya. Identifikasi dampak lingkungan yang ditimbulkan serta upaya pengelolaan dan pemantauan lingkungannya dapat dilihat pada tabel matrik berikut.

Tabel 1. Matriks Pengelolaan dan Pemantauan Lingkungan

\begin{tabular}{|c|c|c|c|c|c|c|c|}
\hline \multirow{2}{*}{$\begin{array}{l}\text { Sumber } \\
\text { Dampak }\end{array}$} & \multirow{2}{*}{$\begin{array}{c}\text { Jenis } \\
\text { Dampak } \\
\text { Lingkunga } \\
\mathbf{n}\end{array}$} & \multirow[b]{2}{*}{ Tolok Ukur } & \multirow{2}{*}{$\begin{array}{l}\text { Besaran } \\
\text { Dampak }\end{array}$} & \multicolumn{2}{|c|}{ Upaya Pengelolaan Lingkungan } & \multicolumn{2}{|c|}{$\begin{array}{l}\text { Upaya Pemantauan } \\
\text { Lingkungan }\end{array}$} \\
\hline & & & & Metode Pengelolaan & $\begin{array}{l}\text { Lokasi } \\
\text { Pengelol } \\
\text { aan } \\
\text { Lingkun } \\
\text { gan }\end{array}$ & $\begin{array}{c}\text { Metode } \\
\text { Pemantauan }\end{array}$ & $\begin{array}{c}\text { Lokasi } \\
\text { Pemantauan } \\
\text { Lingkungan }\end{array}$ \\
\hline \multirow[t]{2}{*}{$\begin{array}{l}\text { Penyiapan } \\
\text { Lahan dan } \\
\text { Pemasangan } \\
\text { Patok Serta } \\
\text { Pembuatan } \\
\text { Pagar } \\
\text { Keliling }\end{array}$} & $\begin{array}{l}\text { Peningkatan } \\
\text { Debu dan } \\
\text { Penurunan } \\
\text { Kualit } \\
\text { as } \\
\text { Udara } \\
\end{array}$ & $\begin{array}{l}\text { Peraturan } \\
\text { Gubernur } \\
\text { Jawa Timur } \\
\text { No. } 10 \text { Tahun } \\
2009 \text { tentang }\end{array}$ & $\begin{array}{l}\text { Kadar debu } \\
>0,26 \\
\mathrm{mg} / \mathrm{Nm}^{3} \\
\text { Kadar } \mathrm{CO} \\
>20 \mathrm{ppm}\end{array}$ & $\begin{array}{l}\text { a) Melakukan upaya } \\
\text { pembasahan lahan } \\
\text { pada area kerja } 2 \\
\text { (dua) kali pada siang } \\
\text { dan sore hari }\end{array}$ & $\begin{array}{l}\text { Di seluruh } \\
\text { area } \\
\text { konstruksi }\end{array}$ & $\begin{array}{l}\text { Melakukan } \\
\text { pemantauan ke } \\
\text { lapangan dan } \\
\text { membanding- } \\
\text { kan hasil }\end{array}$ & $\begin{array}{l}\text { Di seluruh } \\
\text { area } \\
\text { konstruksi }\end{array}$ \\
\hline & & $\begin{array}{l}\text { Baku Mutu } \\
\text { Udara } \\
\text { Ambien dan } \\
\text { Emisi } \\
\text { Sumb } \\
\text { er }\end{array}$ & $\begin{array}{l}(22,6 \\
\left.\mu \mathrm{g} / \mathrm{Nm}^{3}\right) ; \\
\operatorname{kadar} \mathrm{NO}_{\mathrm{x}} \\
>0,05 \mathrm{ppm} \\
(92,5 \\
\left.\mu \mathrm{g} / \mathrm{Nm}^{3}\right) \\
\text { kadar }\end{array}$ & $\begin{array}{l}\text { sehingga dapat } \\
\text { mengurangi dan } \\
\text { mencegah } \\
\text { terbangan debu } \\
\text { b)Mengenakan masker } \\
\text { bagi pekerja jika } \\
\text { melakukan kegiatan }\end{array}$ & & $\begin{array}{l}\text { sampling udara } \\
\text { ambien dengan } \\
\text { standar baku } \\
\text { mutu lingkungan }\end{array}$ & \\
\hline
\end{tabular}


NAROTAMA JURNAL TEKNIK SIPIL

e-ISSN: 2460-3430

VOLUME 4 NOMOR 2 NOPEMBER 2020

\begin{tabular}{|c|c|c|c|c|c|c|c|}
\hline & & $\begin{array}{l}\text { Tidak } \\
\text { Bergerak di } \\
\text { Jawa Timur }\end{array}$ & $\begin{array}{l}\mathrm{SO} 2>0,1 \\
\mathrm{ppm}(262 \\
\left.\mu \mathrm{g} / \mathrm{Nm}^{3}\right)\end{array}$ & $\begin{array}{l}\text { yang menimbulkan } \\
\text { debu atau polusi udara } \\
\text { cukup tinggi }\end{array}$ & & & \\
\hline & $\begin{array}{l}\text { Peningkatan } \\
\text { Kebisingan }\end{array}$ & $\begin{array}{l}\text { Keputusan } \\
\text { Menteri } \\
\text { Lingkunga } \\
\mathrm{n} \\
\text { Hidup } \\
\text { Nomer: KEP- } \\
\text { 48/MENLH/ } \\
\text { 11/1996 } \\
\text { tentang Baku } \\
\text { Mutu } \\
\text { Kebisingan } \\
\end{array}$ & $\begin{array}{l}\text { Tingkat } \\
\text { kebisingan }\end{array}$ & $\begin{array}{l}\text { Kegiatan yang } \\
\text { menghasilkan } \\
\text { kebisingan cukup } \\
\text { tinggi, hendaknya } \\
\text { tidak dilakukan pada } \\
\text { malam hari }\end{array}$ & $\begin{array}{l}\text { Di seluruh } \\
\text { area } \\
\text { konstruksi }\end{array}$ & $\begin{array}{l}\text { Melakukan } \\
\text { pemantauan ke } \\
\text { lapangan dan } \\
\text { membanding- } \\
\text { kan hasil } \\
\text { sampling } \\
\text { kebisingan } \\
\text { dengan standar } \\
\text { baku mutu } \\
\text { lingkungan }\end{array}$ & $\begin{array}{l}\text { Di seluruh } \\
\text { area konstruksi }\end{array}$ \\
\hline $\begin{array}{l}\text { Mobilis } \\
\text { asi } \\
\text { Tenaga } \\
\text { Kerja }\end{array}$ & $\begin{array}{l}\text { Peningkat } \\
\text { an } \\
\text { Kesempat } \\
\text { an Kerja }\end{array}$ & $\begin{array}{l}\text { Jumlah } \\
\text { tenaga } \\
\text { yang } \\
\text { diserap }\end{array}$ & $\begin{array}{l}\text { Penyerap } \\
\text { an tenaga } \\
\text { kerja } \\
\text { konstruks } \\
\text { i } \\
\text { sebanyak } \\
25 \text { orang }\end{array}$ & $\begin{array}{l}\text { a) Menginformasikan } \\
\text { kepada masyarakat } \\
\text { sekitar mengenai } \\
\text { kesempatan kerja } \\
\text { konstruksi yang } \\
\text { tersedia melalui } \\
\text { pengumuman } \\
\text { dengan memasang } \\
\text { banner horizontal } \\
\text { dan pengumuman di } \\
\text { Kantor Balai Desa } \\
\text { dan Kecamatan } \\
\text { serta komunikasi } \\
\text { langsung kepada } \\
\text { masyarakat yang } \\
\text { dianggap memenuhi } \\
\text { kriteria yang } \\
\text { dibutuhkan } \\
\text { b)Menggunakan } \\
\text { tenaga kerja lokal } \\
\text { sesuai dengan } \\
\text { keahlian yang } \\
\text { dibutuhkan. }\end{array}$ & $\begin{array}{l}\text { Pemukim } \\
\text { an } \\
\text { pendudu } \\
\text { k sekitar } \\
\text { lokasi } \\
\text { proyek }\end{array}$ & $\begin{array}{l}\text { Menghitung } \\
\text { jumlah } \\
\text { pemenuhan } \\
\text { kebutuhan } \\
\text { tenaga kerja dari } \\
\text { masyarakat } \\
\text { sekitar }\end{array}$ & $\begin{array}{l}\text { Pemukiman } \\
\text { penduduk } \\
\text { sekitar lokasi } \\
\text { proyek }\end{array}$ \\
\hline \multirow[t]{2}{*}{$\begin{array}{l}\text { Mobilisasi } \\
\text { dan } \\
\text { Demobilisa } \\
\text { si } \\
\text { Material } \\
\text { dan } \\
\text { Peralatan }\end{array}$} & $\begin{array}{l}\text { Peningkata } \\
\mathrm{n} \\
\text { Debu dan } \\
\text { Penurunan } \\
\text { Kualitas } \\
\text { Udara }\end{array}$ & $\begin{array}{l}\text { Peraturan } \\
\text { Gubernur } \\
\text { Jawa Timur } \\
\text { No. 10 } \\
\text { Tahun } \\
2009 \text { tentang } \\
\text { Baku Mutu } \\
\text { Udara } \\
\text { Ambien dan } \\
\text { Emisi } \\
\text { Sumber } \\
\text { Tidak } \\
\text { Bergerak di } \\
\text { Jawa Timur }\end{array}$ & $\begin{array}{l}\text { Kadar debu } \\
>0,26 \\
\mathrm{mg} / \mathrm{Nm}^{3} \text {; } \\
\text { Kadar CO } \\
>20 \mathrm{ppm} \\
(22,6 \\
\left.\mu \mathrm{g} / \mathrm{Nm}^{3}\right) ; \\
\mathrm{kadar} \mathrm{NO} \\
>0,05 \mathrm{ppm} \\
(92,5 \\
\left.\mu \mathrm{g} / \mathrm{Nm}^{3}\right) ; \\
\mathrm{kadar} \\
\mathrm{SO} 2>0,1 \\
\mathrm{ppm} \\
(262 \\
\left.\mu \mathrm{gg} / \mathrm{Nm}^{3}\right)\end{array}$ & $\begin{array}{l}\text { a) Melakukan upaya } \\
\text { pembasahan lahan } \\
\text { pada area kerja } 2 \\
\text { (dua) kali pada } \\
\text { siang dan sore hari } \\
\text { sehingga dapat } \\
\text { mengurangi dan } \\
\text { mencegah } \\
\text { terbangan debu } \\
\text { b) Mengenakan } \\
\text { masker bagi pekerja } \\
\text { jika melakukan } \\
\text { kegiatan yang } \\
\text { menimbulkan debu } \\
\text { atau polusi udara } \\
\text { cukup tinggi }\end{array}$ & $\begin{array}{l}\text { Di seluruh } \\
\text { area } \\
\text { konstruksi }\end{array}$ & $\begin{array}{l}\text { Melakukan } \\
\text { pemantauan ke } \\
\text { lapangan dan } \\
\text { membandingkan } \\
\text { hasil sampling } \\
\text { udara ambien } \\
\text { dengan standar } \\
\text { baku mutu } \\
\text { lingkungan }\end{array}$ & $\begin{array}{l}\text { Di seluruh } \\
\text { area } \\
\text { konstruksi }\end{array}$ \\
\hline & $\begin{array}{l}\text { Kerusakan } \\
\text { Jalan }\end{array}$ & $\begin{array}{l}\text { Terjadi } \\
\text { kerusakan } \\
\text { pada jalan } \\
\text { akses } \\
\text { mobilisasi } \\
\text { dan } \\
\text { demobilisasi } \\
\text { material dan } \\
\text { peralatan }\end{array}$ & $\begin{array}{l}\text { Kerusakan } \\
\text { pada akses } \\
\text { jalan di } \\
\text { sekitar } \\
\text { proyek }\end{array}$ & $\begin{array}{l}\text { a) Kapasitas } \\
\text { kendaraan } \\
\text { pengangkut yang } \\
\text { digunakan } \\
\text { disesuaikan dengan } \\
\text { kelas jalan } \\
\text { b) Melakukan } \\
\text { perbaikan jalan } \\
\text { terhadap jalan yang } \\
\text { rusak akibat } \\
\text { mobilisasi dan } \\
\text { demobilisasi }\end{array}$ & $\begin{array}{l}\text { Jalan } \\
\text { akses } \\
\text { mobilisasi } \\
\text { dan } \\
\text { demobilis } \\
\text { asi } \\
\text { material } \\
\text { sekitar } \\
\text { area } \\
\text { konstruksi }\end{array}$ & $\begin{array}{l}\text { Melakukan } \\
\text { pengamatan } \\
\text { langsung ke } \\
\text { lapangan terkait } \\
\text { kondisi jalan } \\
\text { akses di } \\
\text { lingkungan dekat } \\
\text { di seluruh area } \\
\text { konstruksi }\end{array}$ & $\begin{array}{l}\text { Jalan akses } \\
\text { mobilisasi dan } \\
\text { demobilisasi } \\
\text { material } \\
\text { sekitar area } \\
\text { konstruksi }\end{array}$ \\
\hline
\end{tabular}


NAROTAMA JURNAL TEKNIK SIPIL

e-ISSN: 2460-3430

VOLUME 4 NOMOR 2 NOPEMBER 2020

\begin{tabular}{|c|c|c|c|c|c|c|c|}
\hline & & & & $\begin{array}{l}\text { material dan } \\
\text { peralatan radius } \\
100 \text { meter }\end{array}$ & & & \\
\hline & $\begin{array}{l}\text { Peningkata } \\
\mathrm{n} \\
\text { Kepadatan } \\
\text { Lalu Lintas }\end{array}$ & $\begin{array}{l}\text { Jumlah } \\
\text { bangkitan } \\
\text { kendaraan } \\
\text { dari proyek } \\
\text { sehingga } \\
\text { menimbul- } \\
\text { kan } \\
\text { kemacetan } \\
\text { lalu lintas } \\
\text { dan } \\
\text { gangguan } \\
\text { kenyamanan } \\
\text { pengguna } \\
\text { kendaraan } \\
\text { lainnya }\end{array}$ & $\begin{array}{l}\text { Timbulnya } \\
\text { kemacetan } \\
\text { lalu lintas } \\
\text { yang } \\
\text { menggangg } \\
\text { u } \\
\text { kenyamana } \\
\text { n pengguna } \\
\text { kendaraan } \\
\text { lainnya }\end{array}$ & $\begin{array}{l}\text { a) Pengaturan jam } \\
\text { kegiatan mobilisasi } \\
\text { dan demobilisasi } \\
\text { material dan } \\
\text { peralatan agar tidak } \\
\text { dilakukan pada saat } \\
\text { jam sibuk lalu lintas } \\
\text { b) Menyediakan } \\
\text { petugas parkir } \\
\text { minimal } 1 \text { orang } \\
\text { yang dapat } \\
\text { mengatur kegiatan } \\
\text { keluar masuk } \\
\text { kendaraan proyek }\end{array}$ & $\begin{array}{l}\text { Jalan } \\
\text { akses } \\
\text { menuju } \\
\text { proyek }\end{array}$ & $\begin{array}{l}\text { Pengamatan } \\
\text { langsung ke } \\
\text { lapangan terkait } \\
\text { terjadinya } \\
\text { bangkitan } \\
\text { kendaraan dari } \\
\text { proyek }\end{array}$ & $\begin{array}{l}\text { Jalan akses } \\
\text { menuju } \\
\text { proyek }\end{array}$ \\
\hline \multirow[t]{2}{*}{$\begin{array}{l}\text { Pembangu- } \\
\text { nan dan } \\
\text { Pengopera- } \\
\text { sian } \\
\text { Basecamp } \\
\text { (Aktivitas } \\
\text { Pekerja) }\end{array}$} & $\begin{array}{l}\text { Peningkata } \\
\text { n Air } \\
\text { Limbah } \\
\text { Domestik }\end{array}$ & $\begin{array}{l}\text { Peraturan } \\
\text { Gubernur } \\
\text { Jatim No. } 72 \\
\text { tahun 2013 } \\
\text { tentang Baku } \\
\text { Mutu Air } \\
\text { Limbah Bagi } \\
\text { Industri } \\
\text { dan/atau } \\
\text { Kegiatan } \\
\text { Usaha } \\
\text { Lainnya }\end{array}$ & $\begin{array}{l}\text { Volume air } \\
\text { limbah } \\
\text { domestik } 2 \\
\mathrm{~m}^{3} / \mathrm{hari} \\
(\mathrm{BOD}>30 \\
\mathrm{mg} / \mathrm{l} \text {; COD } \\
\text { > } 50 \mathrm{mg} / \mathrm{l} ; \\
\mathrm{TSS} \\
\text { > } 50 \mathrm{mg} / \mathrm{l} ; \\
\text { Minyak dan } \\
\text { lemak > 10 } \\
\text { mg/l; pH 6- } \\
\text { 9) }\end{array}$ & $\begin{array}{l}\text { Menyediakan sanitasi } \\
\text { yang baik dan } \\
\text { menyediakan } \\
\text { saluran air limbah } \\
\text { untuk menyalurkan } \\
\text { air limbah yang } \\
\text { dihasilkan ke unit } \\
\text { pengolahan air } \\
\text { limbah domestik } \\
\text { seperti tangki septik } \\
\text { biofilter }\end{array}$ & $\begin{array}{l}\text { Di seluruh } \\
\text { area } \\
\text { konstruksi }\end{array}$ & $\begin{array}{l}\text { Melakukan uji } \\
\text { kualitas air } \\
\text { limbah domestik } \\
\text { dan membanding- } \\
\text { kan hasilnya } \\
\text { dengan standar } \\
\text { baku mutu }\end{array}$ & $\begin{array}{l}\text { Outlet } \\
\text { instalasi } \\
\text { pengolahan } \\
\text { air limbah } \\
\text { domestik }\end{array}$ \\
\hline & $\begin{array}{l}\text { Peningkata } \\
\text { n Limbah } \\
\text { Padat } \\
\text { Domestik }\end{array}$ & $\begin{array}{l}\text { UU No. } 18 \\
\text { Tahun } 2008 \\
\text { tentang } \\
\text { Pengelolaan } \\
\text { Sampah }\end{array}$ & $\begin{array}{l}\text { Volume } \\
\text { limbah } \\
\text { padat } \\
\text { domestik } \\
75 \mathrm{~L} / \text { hari }\end{array}$ & $\begin{array}{l}\text { a) Menerapkan aturan } \\
\text { untuk menjaga } \\
\text { kebersihan } \\
\text { lingkungan kepada } \\
\text { seluruh pekerja } \\
\text { b) Mengumpulkan } \\
\text { limbah padat yang } \\
\text { masih dapat } \\
\text { digunakan kembali } \\
\text { atau memiliki nilai } \\
\text { jual } \\
\text { c) Menyediakan dan } \\
\text { menggunakan } \\
\text { fasilitas tempat } \\
\text { pembuangan } \\
\text { sampah sementara } \\
\text { di area proyek } \\
\text { berupa bak sampah } \\
\text { sesuai dengan } \\
\text { karakteristik } \\
\text { sampah } \\
\text { d)Memanfaatkan } \\
\text { fasilitas } \\
\text { pengumpulan dan } \\
\text { pengangkutan } \\
\text { sampah menuju } \\
\text { TPA Kab. } \\
\text { Bangkalan }\end{array}$ & $\begin{array}{l}\text { Di seluruh } \\
\text { area } \\
\text { konstruksi } \\
\text { khususnya } \\
\text { tempat } \\
\text { pengumpu } \\
\text { - lan dan } \\
\text { pembuang } \\
\text { an sampah } \\
\text { domestik }\end{array}$ & $\begin{array}{l}\text { a) Melakukan } \\
\text { pengamatan } \\
\text { terhadap } \\
\text { timbulan } \\
\text { dan kondisi } \\
\text { pewadahan } \\
\text { limbah } \\
\text { padat } \\
\text { domestik } \\
\text { b) Melakukan } \\
\text { pemantauan } \\
\text { langsung ke } \\
\text { lapangan dan } \\
\text { memban- } \\
\text { dingkan } \\
\text { jumlah } \\
\text { limbah padat } \\
\text { yang } \\
\text { tertangani } \\
\text { dengan } \\
\text { jumlah } \\
\text { limbah padat } \\
\text { yang } \\
\text { dihasilkan }\end{array}$ & $\begin{array}{l}\text { Di seluruh } \\
\text { area } \\
\text { konstruksi } \\
\text { khususnya } \\
\text { tempat } \\
\text { pengumpulan } \\
\text { dan } \\
\text { pembuangan } \\
\text { sampah } \\
\text { domestik }\end{array}$ \\
\hline $\begin{array}{l}\text { Pekerjaan } \\
\text { Struktur, } \\
\text { Mechanica } \\
1 \&\end{array}$ & $\begin{array}{l}\text { Peningkata } \\
\text { n Debu dan } \\
\text { Penurunan } \\
\text { Kualitas }\end{array}$ & $\begin{array}{l}\text { Peraturan } \\
\text { Gubernur } \\
\text { Jawa Timur } \\
\text { No. } 10\end{array}$ & $\begin{array}{l}\text { Kadar debu } \\
>0,26 \\
\text { mg/Nm3; } \\
\text { Kadar CO }\end{array}$ & $\begin{array}{l}\text { a) Melakukan upaya } \\
\text { pembasahan lahan } \\
\text { pada area kerja } 2 \\
\text { (dua) kali pada }\end{array}$ & $\begin{array}{l}\text { Di seluruh } \\
\text { area } \\
\text { konstruksi }\end{array}$ & $\begin{array}{l}\text { Melakukan } \\
\text { pemantauan ke } \\
\text { lapangan dan } \\
\text { membanding- }\end{array}$ & $\begin{array}{l}\text { Di seluruh } \\
\text { area } \\
\text { konstruksi }\end{array}$ \\
\hline
\end{tabular}


NAROTAMA JURNAL TEKNIK SIPIL

e-ISSN: 2460-3430

VOLUME 4 NOMOR 2 NOPEMBER 2020

\begin{tabular}{|c|c|c|c|c|c|c|c|}
\hline \multirow[t]{3}{*}{$\begin{array}{l}\text { Electrical } \\
\text { (M\&E) } \\
\text { dan Sarana } \\
\text { Penunjang- } \\
\text { nya }\end{array}$} & Udara & \begin{tabular}{l|} 
Tahun \\
2009 tentang \\
Baku Mutu \\
Udara \\
Ambien dan \\
Emisi \\
Sumber \\
Tidak \\
Bergerak di \\
Jawa Timur
\end{tabular} & $\begin{array}{l}>20 \mathrm{ppm} \\
(22,6 \\
\mu \mathrm{g} / \mathrm{Nm} 3) ; \\
\text { kadar NOx } \\
>0,05 \mathrm{ppm} \\
(92,5 \\
\mu \mathrm{g} / \mathrm{Nm} 3) ; \\
\text { kadar } \\
\mathrm{SO} 2>0,1 \\
\mathrm{ppm}(262 \\
\mu \mathrm{g} / \mathrm{Nm} 3)\end{array}$ & $\begin{array}{l}\text { siang dan sore hari } \\
\text { sehingga dapat } \\
\text { mengurangi dan } \\
\text { mencegah } \\
\text { terbangan debu } \\
\text { b) Mengenakan } \\
\text { masker bagi pekerja } \\
\text { jika melakukan } \\
\text { kegiatan yang } \\
\text { menimbulkan debu } \\
\text { atau polusi udara } \\
\text { cukup tinggi }\end{array}$ & & $\begin{array}{l}\text { kan hasil } \\
\text { sampling } \\
\text { udara ambien } \\
\text { dengan standar } \\
\text { baku mutu } \\
\text { lingkungan }\end{array}$ & \\
\hline & $\begin{array}{l}\text { Peningkata } \\
\mathrm{n} \\
\text { Kebisingan }\end{array}$ & $\begin{array}{l}\text { Keputusan } \\
\text { Menteri } \\
\text { Lingkungan } \\
\text { Hidup } \\
\text { Nomer: } \\
\text { KEP- } \\
\text { 48/MENLH/ } \\
\text { 11/1996 } \\
\text { tentang Baku } \\
\text { Mutu } \\
\text { Kebisingan }\end{array}$ & $\begin{array}{l}\text { Tingkat } \\
\text { kebisingan }\end{array}$ & $\begin{array}{l}\text { Kegiatan yang } \\
\text { menghasilkan } \\
\text { kebisingan cukup } \\
\text { tinggi hendaknya } \\
\text { tidak dilakukan } \\
\text { pada malam hari } \\
\text { (waktu istirahat } \\
\text { masyarakat sekitar } \\
\text { lokasi operasional) }\end{array}$ & $\begin{array}{l}\text { Di seluruh } \\
\text { area } \\
\text { konstruksi }\end{array}$ & $\begin{array}{l}\text { Melakukan } \\
\text { pemantauan ke } \\
\text { lapangan dan } \\
\text { membandingk } \\
\text { an hasil } \\
\text { sampling } \\
\text { Kebisingan } \\
\text { dengan standar } \\
\text { baku mutu } \\
\text { lingkungan }\end{array}$ & $\begin{array}{l}\text { Di seluruh } \\
\text { area } \\
\text { konstruksi }\end{array}$ \\
\hline & $\begin{array}{l}\text { Resiko } \\
\text { Kecelakaan } \\
\text { Kerja dan } \\
\text { Penurunan } \\
\text { Kesehatan } \\
\text { Pekerja }\end{array}$ & $\begin{array}{l}\text { Jumlah } \\
\text { kecelakaan } \\
\text { kerja dan } \\
\text { penurunan } \\
\text { kesehatan } \\
\text { pekerja yang } \\
\text { terjadi }\end{array}$ & $\begin{array}{l}\text { Terjadi } \\
\text { kecelakaan } \\
\text { kerja yang } \\
\text { menyebab- } \\
\text { kan } \\
\text { kecelakaan } \\
\text { ringan, } \\
\text { berat } \\
\text { hingga } \\
\text { menyebab- } \\
\text { kan } \\
\text { kematian } \\
\text { atau } \\
\text { mengalami } \\
\text { penurunan } \\
\text { kesehatan }\end{array}$ & $\begin{array}{l}\text { a) Memberikan safety } \\
\text { briefing dan general } \\
\text { precautions kepada } \\
\text { pekerja secara } \\
\text { berkala tentang } \\
\text { pentingnya } \\
\text { keselamatan kerja } \\
\text { serta menggunakan } \\
\text { APD yang } \\
\text { memadai } \\
\text { b) Bekerja sama } \\
\text { dengan perusahaan } \\
\text { asuransi dan } \\
\text { diikutkan program } \\
\text { BPJS } \\
\text { Ketenagakerjaan } \\
\text { untuk melindungi } \\
\text { kepentingan } \\
\text { pekerja }\end{array}$ & $\begin{array}{l}\text { Di seluruh } \\
\text { area } \\
\text { konstruksi }\end{array}$ & $\begin{array}{l}\text { a) Pengamatan } \\
\text { secara visual } \\
\text { terhadap alat } \\
\text { dan } \\
\text { prosedur } \\
\text { keamanan } \\
\text { yang } \\
\text { digunakan } \\
\text { b) Melakukan } \\
\text { evaluasi } \\
\text { terhadap } \\
\text { prosedur } \\
\text { yang } \\
\text { digunakan } \\
\text { berdasarkan } \\
\text { jumlah } \\
\text { kecelakaan } \\
\text { kerja dan } \\
\text { penurunan } \\
\text { kesehatan } \\
\text { pekerja }\end{array}$ & $\begin{array}{l}\text { Di seluruh } \\
\text { area } \\
\text { konstruksi }\end{array}$ \\
\hline & $\begin{array}{l}\text { Peningkata } \\
\text { n Limbah } \\
\text { Padat Sisa } \\
\text { Material }\end{array}$ & $\begin{array}{l}\text { UU No. } 18 \\
\text { Tahun } 2008 \\
\text { tentang } \\
\text { Pengelolaan } \\
\text { Sampah }\end{array}$ & $\begin{array}{l}\text { Volume } \\
\text { limbah } \\
\text { padat sisa } \\
\text { material } \\
100 \mathrm{~L} / \mathrm{Hari}\end{array}$ & $\begin{array}{l}\text { a) Menerapkan aturan } \\
\text { untuk menjaga } \\
\text { kebersihan } \\
\text { lingkungan } \\
\text { kepada seluruh } \\
\text { pekerjaan } \\
\text { b) Mengumpulkan } \\
\text { limbah padat } \\
\text { yang masih } \\
\text { dapat digunakan } \\
\text { kembali atau } \\
\text { memiliki nilai } \\
\text { jual } \\
\text { c) Menyediakan dan } \\
\text { menggunakan } \\
\text { fasilitas tempat } \\
\text { pembuangan } \\
\text { sampah } \\
\text { sementara berupa } \\
\text { bak sampah } \\
\text { karung sesuai }\end{array}$ & $\begin{array}{l}\text { Di seluruh } \\
\text { area } \\
\text { konstruksi } \\
\text { khususnya } \\
\text { tempat } \\
\text { pengumpu } \\
\text { lan dan } \\
\text { pembuang } \\
\text { an sampah } \\
\text { - }\end{array}$ & $\begin{array}{l}\text { a)Melakukan } \\
\text { pengamatan } \\
\text { terhadap } \\
\text { timbulan } \\
\text { limbah padat } \\
\text { sisa material } \\
\text { dan kondisi } \\
\text { pewadahan } \\
\text { limbah padat } \\
\text { sisa material } \\
\text { b)Melakukan } \\
\text { pemantauan } \\
\text { langsung ke } \\
\text { lapangan dan } \\
\text { membanding- } \\
\text { kan jumlah } \\
\text { limbah padat } \\
\text { yang } \\
\text { tertangani } \\
\text { dengan jumlah } \\
\text { limbah padat }\end{array}$ & $\begin{array}{l}\text { Di seluruh } \\
\text { area } \\
\text { konstruksi } \\
\text { khususnya } \\
\text { tempat } \\
\text { pengumpulan } \\
\text { dan } \\
\text { pembuangan } \\
\text { sampah }\end{array}$ \\
\hline
\end{tabular}


NAROTAMA JURNAL TEKNIK SIPIL

e-ISSN: 2460-3430

VOLUME 4 NOMOR 2 NOPEMBER 2020

\begin{tabular}{|c|c|c|c|c|c|c|c|}
\hline & & & & $\begin{array}{l}\text { dengan } \\
\text { karakteristik } \\
\text { limbah padat } \\
\text { d) Memanfaatkan } \\
\text { fasilitas } \\
\text { pengumpulan } \\
\text { dan } \\
\text { pengangkutan } \\
\text { sampah menuju } \\
\text { TPA Kab. } \\
\text { Bangkalan } \\
\end{array}$ & & $\begin{array}{l}\text { yang } \\
\text { dihasilkan }\end{array}$ & \\
\hline \multirow[t]{2}{*}{$\begin{array}{l}\text { Pekerjaan } \\
\text { Landscapin } \\
\text { g dan } \\
\text { Finishing }\end{array}$} & $\begin{array}{l}\text { Resiko } \\
\text { Kecelakaan } \\
\text { Kerja dan } \\
\text { Penurunan } \\
\text { Kesehatan } \\
\text { Pekerja }\end{array}$ & $\begin{array}{l}\text { Jumlah } \\
\text { kecelakaan } \\
\text { kerja dan } \\
\text { penurunan } \\
\text { kesehatan } \\
\text { pekerja yang } \\
\text { terjadi }\end{array}$ & $\begin{array}{l}\text { Terjadi } \\
\text { kecelakaan } \\
\text { kerja yang } \\
\text { menyebab- } \\
\text { kan } \\
\text { kecelakaan } \\
\text { ringan, } \\
\text { berat } \\
\text { hingga } \\
\text { menyebab- } \\
\text { kan } \\
\text { kematian } \\
\text { atau } \\
\text { mengalami } \\
\text { penurunan } \\
\text { kesehatan }\end{array}$ & $\begin{array}{l}\text { a) Memberikan safety } \\
\text { briefing dan } \\
\text { general } \\
\text { precautions } \\
\text { kepada pekerja } \\
\text { secara berkala } \\
\text { tentang } \\
\text { pentingnya } \\
\text { keselamatan } \\
\text { kerja serta } \\
\text { menggunakan } \\
\text { APD yang } \\
\text { memadai } \\
\text { b) Bekerja sama } \\
\text { dengan } \\
\text { perusahaan } \\
\text { asuransi dan } \\
\text { diikutkan } \\
\text { program BPJS } \\
\text { untuk } \\
\text { melindungi } \\
\text { kepentingan } \\
\text { pekerja }\end{array}$ & $\begin{array}{l}\text { Di seluruh } \\
\text { area } \\
\text { konstruksi }\end{array}$ & $\begin{array}{l}\text { a) Pengamatan } \\
\text { secara visual } \\
\text { terhadap alat } \\
\text { dan } \\
\text { prosedur } \\
\text { keamanan } \\
\text { yang } \\
\text { digunakan } \\
\text { b) Melakuka } \\
\text { n evaluasi } \\
\text { Terhadap } \\
\text { prosedur yang } \\
\text { digunakan } \\
\text { berdasarkan } \\
\text { jumlah } \\
\text { kecelakaan } \\
\text { kerja dan } \\
\text { penurunan } \\
\text { kesehatan } \\
\text { pekerja }\end{array}$ & $\begin{array}{l}\text { Di seluruh } \\
\text { area } \\
\text { konstruksi }\end{array}$ \\
\hline & $\begin{array}{l}\text { Peningkata } \\
\text { n Limbah } \\
\text { Padat Sisa } \\
\text { Material }\end{array}$ & $\begin{array}{l}\text { UU No. } 18 \\
\text { Tahun } 2008 \\
\text { tentang } \\
\text { Pengelolaan } \\
\text { Sampah }\end{array}$ & $\begin{array}{l}\text { Volume } \\
\text { limbah } \\
\text { padat sisa } \\
\text { material } \\
100 \mathrm{~L} / \mathrm{Hari}\end{array}$ & $\begin{array}{l}\text { a) Menerapkan aturan } \\
\text { untuk menjaga } \\
\text { kebersihan } \\
\text { lingkungan kepada } \\
\text { seluruh pekerja } \\
\text { b) Mengumpulkan } \\
\text { limbah padat yang } \\
\text { masih dapat } \\
\text { digunakan kembali } \\
\text { atau memiliki nilai } \\
\text { jual } \\
\text { c) Menyediakan dan } \\
\text { menggunakan } \\
\text { fasilitas tempat } \\
\text { pembuangan } \\
\text { sampah sementara } \\
\text { berupa bak sampah } \\
\text { karung sesuai } \\
\text { dengan karakteristik } \\
\text { limbah } \\
\text { Padat } \\
\text { d)Memanfaatkan } \\
\text { fasilitas } \\
\text { pengumpulan dan } \\
\text { pengangkutan } \\
\text { sampah menuju } \\
\text { TPA Kab. } \\
\text { Bangkalan }\end{array}$ & $\begin{array}{l}\text { Di seluruh } \\
\text { area } \\
\text { konstruksi } \\
\text { khususnya } \\
\text { tempat } \\
\text { pengumpu } \\
\text { - lan dan } \\
\text { pembuang } \\
\text { an sampah }\end{array}$ & $\begin{array}{l}\text { a) Melakukan } \\
\text { pengamatan } \\
\text { terhadap } \\
\text { timbulan } \\
\text { limbah } \\
\text { padat sisa } \\
\text { material dan } \\
\text { kondisi } \\
\text { pewadahan } \\
\text { limbah } \\
\text { padat sisa } \\
\text { material } \\
\text { b) Melakukan } \\
\text { pemantauan } \\
\text { langsung ke } \\
\text { lapangan dan } \\
\text { membanding- } \\
\text { kan jumlah } \\
\text { limbah padat } \\
\text { yang } \\
\text { tertangani } \\
\text { dengan } \\
\text { jumlah } \\
\text { limbah padat } \\
\text { yang } \\
\text { dihasilkan }\end{array}$ & $\begin{array}{l}\text { Di seluruh } \\
\text { area } \\
\text { konstruksi } \\
\text { khususnya } \\
\text { tempat } \\
\text { pengumpulan } \\
\text { dan } \\
\text { pembuangan } \\
\text { sampah }\end{array}$ \\
\hline
\end{tabular}


NAROTAMA JURNAL TEKNIK SIPIL

e-ISSN: 2460-3430

VOLUME 4 NOMOR 2 NOPEMBER 2020

\begin{tabular}{|c|c|c|c|c|c|c|c|}
\hline $\begin{array}{l}\text { Demobilisa } \\
\text { si Tenaga } \\
\text { Kerja }\end{array}$ & $\begin{array}{l}\text { Penurunan } \\
\text { Kesempata } \\
\text { n Kerja }\end{array}$ & $\begin{array}{l}\text { Jumlah } \\
\text { tenaga yang } \\
\text { didemobili- } \\
\text { sasi }\end{array}$ & \begin{tabular}{l|}
25 orang \\
tenaga kerja \\
yang \\
didemobili- \\
sasi berasal \\
dari \\
lingkungan \\
sekitar \\
proyek
\end{tabular} & $\begin{array}{l}\text { a) Pemberian } \\
\text { pesangon } \\
\text { yang layak } \\
\text { kepada } \\
\text { pekerja yang } \\
\text { didemobilisasi } \\
\text { b) Menginformasikan } \\
\text { kepada tenaga kerja } \\
\text { yang akan } \\
\text { didemobilisasi pada } \\
\text { saat awal rekrutmen } \\
\text { (status sebagai } \\
\text { tenaga kontrak) }\end{array}$ & $\begin{array}{l}\text { Pemukima } \\
\mathrm{n} \\
\text { penduduk } \\
\text { sekitar } \\
\text { lokasi } \\
\text { proyek }\end{array}$ & $\begin{array}{l}\text { Dilakukan } \\
\text { pengamatan } \\
\text { langsung ke } \\
\text { lapangan } \\
\text { terkait } \\
\text { proses } \\
\text { demobilisas } \\
\text { i tenaga } \\
\text { kerja }\end{array}$ & $\begin{array}{l}\text { Pemukiman } \\
\text { penduduk } \\
\text { sekitar lokasi } \\
\text { proyek }\end{array}$ \\
\hline
\end{tabular}

Sumber : Hasil Analisis

\section{SIMPULAN DAN SARAN}

Berdasarkan hasil penelitian diatas maka dapat disimpulkan bahwa setiap kegiatan pada masa konstruksi pembangunan ruko dan gudang real estate kabupaten bangkalan ini mampu menimbulkan dampak kerusakan lingkungan baik dari aspek fisik - kimia maupun sosial - ekonomi, namun rata-rata hanya berlangsung sementara karena dapat dimnimalisasi dengan upaya pengelolaan dan pemantauan lingkungan yang baik.

Komponen fisik - kimia seperti penurunan kualitas udara, adanya peningkatan kerusakan jalan, kebisingan, peningkatan air limbah domestik dan limbah padat dapat terus dipantau dan dilaksanakan upaya minimalisir dampak dengan mengacu pada aturan tolak ukur yang telah ditetapkan. Sementara untuk komponen sosial ekonomi lebih kepada hubungan dengan masyarakat yang dapat dilakukan dengan cara sosialisasi keberadaan proyek tersebut dan perekrutan pekerja konstruksi dari penduduk lokal agar komplain kesenjangan sosial dari masyarakat yakni kekawatiran perekrutan pekerja dari luar bangkalan bukan dari pekerja lokal dapat diminimalisasi, untuk kepadatan lalu lintas akibat bangkitan yang terjadi dapat dilakukan upaya pengaturan manajemen lalu lintas sesuai dengan aturan dari kementerian perhubungan darat dan untuk kecelakaan pekerja maka perlu adanya pengawasan terkait $\mathrm{K} 3$ didalam proyek tersebut agar terciptanya konstruksi yag ramah lingkungan dapat terwujud.

\section{DAFTAR PUSTAKA}

1. Asmadi Asmadi dan Suharno. 2012. Dasar-dasar Teknologi Pengolahan Air Limbah. Gosyen Publishing Yogyakarta.

2. Balai Teknik Air Minum dan Sanitasi Wilayah I. 2010. Modul Bimbingan Teknik tentang dan Pemeliharaan IPLT. Dirjen Cipta Karya Kementrian Pekerjaan Umum. Bekasi.

3. Beanlands, G.E. and P.N Duinker. 1983. An Ecological Framework for Enviromental Assessment Studies. Dalhousie University and Federal Enviromental Assessment Review Office, Hull, P.Q.

4. Damanhuri, Erni dan Tri Padmi. 2010. Diktat Kuliah Pengelolaan Sampah. Institut Teknologi Bandung. Bandung.

5. Peraturan Daerah Kabupaten Bangkalan Nomor 10 Tahun 2009 Tentang Rencana Tata Ruang Wilayah Kabupaten Bangkalan Tahun 2009 - 2029

6. Peraturan Gubernur Jawa Timur No. 10 Tahun 2009 Tentang Baku Mutu Udara Ambien dan Emisi Sumber Tidak Bergerak di Jawa Timur. 
7. Prasetyo D dan Alimuddin. 2018. Kajian Dampak Lingkungan Terhadap Proyek Konstruksi Pembangunan Pembangkit Listrik Tenaga Minihidro (Pltm) Pongkor. Seminar Nasional Sains dan Teknologi (Semnastek). e-ISSN: $2460-$ 8416. Universitas Muhammadiyah Jakarta

8. Purbonegoro T. 2017. Faktor-Faktor Yang Mempengaruhi Toksisitas Bahan Pencemar Terhadap Organisme Perairan. Oseana, Volume XLII no 2 Tahun 2017 e- ISSN 0216-1877. Puslit Oseanografi Lipi Jakarta

9. Slamet. 2007. Kesehatan Lingkungan - Cetakan Ketujuh. Gadjah Mada University Press. Yoyakarta.

10. Undang-Undang Nomor 32 Tahun 2009 Tentang Perlindungan Dan Pengelolaan Lingkungan Hidup 